\title{
Effects of rain shelter or simulated rain during grain filling and maturation on subsequent wheat grain quality in the UK
}

Article

Accepted Version

Yadav, G. and Ellis, R. H. (2017) Effects of rain shelter or simulated rain during grain filling and maturation on subsequent wheat grain quality in the UK. Journal of Agricultural Science, 155 (2). pp. 300-316. ISSN 1469-5146 doi: https://doi.org/10.1017/S0021859616000411 Available at https://centaur.reading.ac.uk/65651/

It is advisable to refer to the publisher's version if you intend to cite from the work. See Guidance on citing.

To link to this article DOI: http://dx.doi.org/10.1017/S0021859616000411

Publisher: Cambridge University Press

All outputs in CentAUR are protected by Intellectual Property Rights law, including copyright law. Copyright and IPR is retained by the creators or other copyright holders. Terms and conditions for use of this material are defined in the End User Agreement.

www.reading.ac.uk/centaur 
Central Archive at the University of Reading

Reading's research outputs online 
Effects of rain shelter or simulated rain during grain filling and maturation on subsequent wheat grain quality in the UK

Short title: Rain shelter, ear wetting and wheat grain quality

G. YADAV $V^{1,2}$ AND R. H. ELLIS ${ }^{1 *}$

${ }^{1}$ School of Agriculture, Policy and Development, University of Reading, Earley Gate, PO Box 237, Reading RG6 6AR, UK

${ }^{2}$ Present address: Division of Soil and Crop Management, ICAR-Central Soil Salinity Research Institute, Zarifa Farm, Kachhwa Road, Karnal-132001, India

(MS received 19 October 2015, revised 1 April 2016, accepted TBC May 2016)

\section{SUMMARY}

The effects of simulated additional rain (ear wetting, $25 \mathrm{~mm}$ ) or of rain shelter imposed at different periods after anthesis on grain quality at maturity and the dynamics of grain filling and desiccation were investigated in UK field-grown crops of wheat (Triticum aestivum L., cvar Tybalt) in 2011 and in 2012 when June-August rainfall was 255.0 and $214.6 \mathrm{~mm}$, respectively, and above the decadal mean $(157.4 \mathrm{~mm})$.

Grain filling and desiccation were quantified well by broken-stick regressions and Gompertz curves, respectively. Rain shelter for 56 (2011) or $70 \mathrm{~d}$ (2012) after anthesis, and to a lesser extent during late maturation only, resulted in more rapid desiccation and hence progress to harvest maturity whereas ear wetting had negligible effects, even when applied four times. Grain-filling duration was also affected as above in 2011, but with no significant effect in 2012. In both years, there were strong positive associations between final grain dry weight and duration of filling.

The treatments affected all grain quality traits in 2011: nitrogen $(\mathrm{N})$ and sulphur (S) concentrations, N:S ratio, sodium dodecyl sulphate (SDS) sedimentation volume, Hagberg 
Falling Number (HFN), and the incidence of blackpoint. Only $\mathrm{N}$ concentration and blackpoint were affected significantly by treatments in 2012. Rain shelter throughout grain filling reduced $\mathrm{N}$ concentration, whereas rain shelter reduced the incidence of blackpoint and ear wetting increased it. In 2011, rain shelter throughout reduced S concentration, increased $\mathrm{N}: \mathrm{S}$ ratio and reduced SDS. Treatment effects on HFN were not consistent within or between years. Nevertheless, a comparison between the extreme treatment means in 2012 indicated damage from late rain combined with ear wetting resulted in a reduction of $c .0 .7 \mathrm{~s}$ in HFN/mm August rainfall, whilst that between samples taken immediately after ear wetting at harvest maturity or $7 \mathrm{~d}$ later suggested recovery from damage to HFN upon re-drying in planta.

Hence, the incidence of blackpoint was the only grain quality trait affected consistently by the diverse treatments. The remaining aspects of grain quality were comparatively resilient to rain incident upon developing and maturing ears of cvar Tybalt. No consistent temporal patterns of sensitivity to shelter or ear wetting were detected for any aspect of grain quality.

\section{INTRODUCTION}

Global land precipitation increased by about $2 \%$ during the 20th century (Jones \& Hulme 1996; Hulme et al. 1998), but by 10-40\% across northern Europe (Klein Tank et al. 2002). Projections for this century indicate warmer climates with more intense and more frequent extreme precipitation events (IPCC 2014).

In wheat (Triticum aestivum L.), reduction in water availability shortens grain-filling duration and so reduces grain size and yield (Nicolas et al. 1984; Gooding et al. 2003), whereas several grain quality traits such as nitrogen $(\mathrm{N})$ concentration, sulphur (S) concentration, sodium dodecyl sulphate (SDS) sedimentation volume and Hagberg Falling Number (HFN) are increased (Gooding et al. 2003). The effects of either absence or excess 
of rainfall during grain development on different aspects of quality can be dependent upon timing. This has been detected within the UK's considerable inter-annual fluctuation in wheat grain quality: analysis of long-term UK climate and production data showed that crude protein $(\mathrm{CP})$ content was reduced by rain (almost $0.1 \mathrm{~g} / \mathrm{kg} / \mathrm{mm}$ ) in May and HFN reduced (about $1 \mathrm{~s} / \mathrm{mm}$ ) by rain in August (Gooding et al. 1997).

End-use quality of grain, for example to mill for bread making, is of considerable importance to the successful marketing of the wheat crop (Gooding \& Davies 1997). Crude protein concentration $(\mathrm{N} \times 5.7)$ affects wheat flour's dough properties (Gooding \& Davies 1997). Sticky doughs, difficult to process, result from low HFN, common in UK-produced wheat (Lunn et al. 2001) indicating high $\alpha$-amylase activity (Kondhare et al. 2015). The SDS sedimentation volume test estimates the presence of high molecular weight proteins, such as glutenins, and thus dough viscosity and elasticity (Fullington et al. 1987; Peña et al. 2002). Grains with low sulphur concentration show low SDS sedimentation volumes (McGrath et al. 1993); bread-making quality is related more to sulphur than protein concentration, with high $\mathrm{N}: \mathrm{S}$ ratios indicating poor protein quality (Zhao et al. 1999). Blackpoint is a different aspect of grain quality affecting flour: the dark discolouration of the embryo end of wheat grains (Williamson 1997) by the fungus Dematiaceous hyphomycetes, the spores of which are produced free in the atmosphere (Hanson \& Christensen 1953; Anon. 1985; Cromey \& Mulholland 1988). It occurs in all the major wheat growing regions of the world (Lorenz 1986).

Rainfall can slow grain drying, but may also promote the germination (sensu strictu or even to visible sprouting) of both wheat grains - so reducing HFN (Kondhare et al. 2015) and/or fungal spores, increasing grain discoloration by blackpoint. Research relevant to the above has tended to rely heavily upon experiments in which water availability has been reduced by imposing drought on growing plants, or from the post-hoc analysis of crop 
production and weather records. The current research, therefore, investigated the consequences for wheat grain quality at maturity from simulated rainfall applied to ears or rain shelter of ears of field-grown crops for different, defined, successive periods of grain development and ripening: can the expected response be detected in the field by altering the environment around the ears? The null hypotheses were, for each grain quality trait, that (a) variation in rainfall incident upon ears had no effect on wheat grain quality; and (b) successive periods of grain development and ripening were equally-insensitive to rainfall in this regard.

\section{MATERIALS AND METHODS}

Crops of wheat cvar Tybalt (NABIM Group 2 milling quality) were grown on a deep sandy loam soil at the University of Reading's Crop Research Unit, Sonning $\left(51^{\circ} 27^{\prime} \mathrm{N}, 0^{\circ} 56^{\prime} \mathrm{W}\right)$. Seeds were sown on 16 March 2011 or 15 March 2012, 4-5 cm deep, with a small-plot drill and then consolidated with a Cambridge roller, with 16 rows $12 \mathrm{~cm}$ apart at 400 seeds $/ \mathrm{m}^{2}$ in plots $7.5 \times 1.9 \mathrm{~m}$ (with $0.6 \mathrm{~m}$ between plots). Standard agronomic practices for the location were applied. In each year the crops followed a 3-year cocksfoot, chicory, red clover ley, designed to provide a uniform site after previous experimentation, add organic matter, and improve soil structure. Soil analyses were carried out in late summer-autumn (300 mm deep for phosphorus $(\mathrm{P})$, potassium $(\mathrm{K})$ and magnesium $(\mathrm{Mg})$ ) and spring (900 mm deep for $\mathrm{N}, \mathrm{S}$ ) for each field experiment. Phosphorus, $\mathrm{K}$ and $\mathrm{Mg}$ indices were 2, 1 and 1 in 2010 and 3, 1 and 1 in 2011, with $59.3 \mathrm{~kg} / \mathrm{ha}$ and $45.3 \mathrm{mg} / \mathrm{l}$ available $\mathrm{N}$ and available sulphate, respectively, in spring 2011 and $60.8 \mathrm{~kg} / \mathrm{ha}$ and $32.0 \mathrm{mg} / \mathrm{l}$ available $\mathrm{N}$ and available sulphate, respectively, in spring 2012. In the 2011 investigation, fertilizers $\left(90 \mathrm{~kg}\right.$ potassium oxide $\left(\mathrm{K}_{2} \mathrm{O}\right) / \mathrm{ha}$ before ploughing in September 2010 and 100 kg N/ha on 13 May 2011), the herbicide Harmony M $\mathrm{SX}$ at $125 \mathrm{~g} / \mathrm{ha}(400 \mathrm{~g} / \mathrm{kg}$ thifensulfuron methyl and $40 \mathrm{~g} / \mathrm{kg}$ metsulfuron methyl; Du Pont, 
Stevenage, UK) on 7 April 2011, and the fungicide Opus at 1 litre/ha in 220 litres water (epoxiconazole; BASF, Cheadle Hulme, UK) on 11 May 2011 were applied. In 2012, fertilizers (102 $\mathrm{kg} \mathrm{K} \mathrm{K}_{2} \mathrm{O} / \mathrm{ha}$ before ploughing in September 2011 and $100 \mathrm{~kg} \mathrm{~N} / \mathrm{ha}$ on 4 May 2012), the herbicide Harmony M SX (as above) on 16 May 2012, and the fungicide Opus (as above) on 21 May 2012 were applied.

Each experiment was a split-plot design, with different harvest dates as sub-plots, with two blocks. In 2011, the 11 main plots comprised open, sheltered (no rainfall), or additional (simulated) rainfall. One plot received no experimental treatment $(\mathrm{C} 1 \mathrm{O}$; open control) whilst another was covered by a full rain shelter from $50 \%$ anthesis until 56 days after 50\% anthesis (DAA) (C2S; sheltered control). Four plots were provided with temporary rain shelter for successive 14 day periods: 0-14 (S1), 14-28 (S2), 28-42 (S3), or 42-56 DAA (S4). Five (open) plots were subject to simulated rain at different periods of grain development: a single ear wetting at 7 (W1), 21 (W2), 35 (W3), or 49 DAA (W4), or four successive wettings at 7, 21, 35 and 49 DAA (W5). In 2012, the ten main plots were: control (C1O; open control) and full rain shelter from 50\% anthesis until 70 DAA (C2S; sheltered control), three temporary rain shelter treatments for the successive periods 42-70 (S1), 42-56 (S2), or 56-70 DAA (S3), and five single ear wettings at 42 (W1), 49 (W2), 56 (W3), 63 (W4), or 70 DAA (W5). In addition, results from samples harvested immediately after treatments W1-5 were designated W.

Rain shelters were $2 \times 5 \times 1.5 \mathrm{~m}$ tall (twice the crop height and open at the sides to aid air circulation and minimize temperature rise above the crop canopy) covered with polythene (VisqueenLumitherm - 11A,Visqueen Building Products, Heanor, UK). Four iButtons (DS1923, HygrochroniButton, Maxim Integrated, San Jose, CA, USA) were installed (two in each block) above the crop canopy to record temperature in control and sheltered plots. Photosynthetically active radiation (PAR) was recorded under each shelter 
using a PAR sensor (AccuPAR model LP-80, Decagon Devices, Inc., Pullman, USA). Each simulated rainfall, ear wetting treatment provided the equivalent of $25 \mathrm{~mm}$ rainfall. Water was applied directly to the ears with a watering can and rose in two part (half) applications, with a 30-min interval.

Samples of ears from each treatment were harvested serially, between 07.00 and $09.00 \mathrm{~h}$, on up to nine occasions during grain development and maturation $(14,25,32,39,46$, 53, 60, 67 and 74 DAA in 2011; 14, 21, 28, 35, 42, 49, 56, 63, 70 and 77 DAA in 2012). Initial samples from ear wetting treatments were taken about $30 \mathrm{~min}$ after the end of the treatment. In 2012, samples were also taken just before ear wetting. The sub-plot area was selected at random within each main plot and 100 ears cut about $1-2 \mathrm{~cm}$ below spikes, placed in loosely-folded polythene bags and taken to the laboratory.

Grains were gently threshed from ears by hand. Grain moisture content and dry weight were estimated for all harvests in order to assess treatment effects on grain filling and desiccation. Grain quality was assessed for the last harvest (21 August 2011, 74 DAA; 27 August 2012, 70 DAA, except in the case of W5 where it was at 77 DAA, i.e. $7 \mathrm{~d}$ after ear wetting, with the sample at 70 DAA designated $\mathrm{W}$ (as above).

Grain moisture content was estimated on a fresh weight basis by the high-constanttemperature-oven method: two replicates of $4-5 \mathrm{~g}$ ground grain dried at $130 \pm 2{ }^{\circ} \mathrm{C}$ for $2 \mathrm{~h}$, with the two-stage procedure for values $>170 \mathrm{~g} / \mathrm{kg}$ (International Seed Testing Association 2011). Grain dry weight was estimated by counting and weighing two replicates of 300 grains and adjusted to $0 \mathrm{~g} / \mathrm{kg}$ moisture content.

Samples were dried to $<150 \mathrm{~g} / \mathrm{kg}$ moisture content at $15-17{ }^{\circ} \mathrm{C}$ with $12-15 \%$ relative humidity, where necessary, and stored in hermetically sealed containers at $0-4{ }^{\circ} \mathrm{C}$ until the subsequent determinations of grain quality. Dried grain samples (10 g) were first milled using a Laboratory Mill 3100 (Perten Instruments AB, Huddinge, Sweden). Nitrogen and sulphur 
concentrations were determined for two replicates of each sample from a $0.20 \mathrm{~g}$ sample of dried wholemeal flour by the oxidative combustion method (Association of Official Analytical Chemists International 2005) using automated Dumas type combustion analysers (LECO FP-528 and LECO SC-144DR, Leco Instruments (UK) Ltd, Stockport, UK). Crude protein $(\mathrm{CP})$ concentration $(\mathrm{g} / \mathrm{kg} \mathrm{DM})$ was calculated by multiplying $\mathrm{N}(\mathrm{g} / \mathrm{kg})$ by 5.7 (Gooding \& Davies 1997).

Hagberg Falling Number was estimated with equipment incorporating automatic agitation (Falling Number 1500; ISO 3093: 1982, British Standards Institution; Perten Instruments, Sweden) with a sample of $7 \mathrm{~g}$ flour at $150 \mathrm{~g} / \mathrm{kg}$ moisture content, in two replicates, suspended in $25 \mathrm{ml}$ distilled water. To estimate SDS sedimentation volume, $6 \mathrm{~g}$ wholemeal wheat flour at $150 \mathrm{~g} / \mathrm{kg}$ moisture content (two replicates for each treatment) was suspended in $50 \mathrm{ml}$ of distilled water in a $100 \mathrm{ml}$ cylinder; $50 \mathrm{ml}$ SDS reagent (stock solution: $20 \mathrm{~g}$ SDS $+20 \mathrm{ml}$ diluted lactic acid in a litre of distilled water) was added and shaken to make a suspension, allowed to settle for $20 \mathrm{~min}$ and sediment volume recorded.

Two replicates of 50 grains from each sub-plot were sampled and each grain scored individually for blackpoint. The score (0-3) varied with the extent of blackening, assessed against reference slides made earlier for this purpose, and so indicated the severity of discoloration: 0, no discoloration; 1, blackening restricted to the embryo region; 2, blackening extending over the shoulders of the grain; 3, blackening covered the majority of the grain surface. The maximum possible score was 150 (i.e. 50 grains scoring 3). Each replicate's total score was expressed as a percentage of the maximum possible score of 150 (i.e. 50 grains scoring 3) using the formula of Lorenz (1986):

Blackpoin $t(\%)=\frac{(\text { Grains scoring } 1)+(\text { Grainsscoring } 2 \times 2)+(\text { Grains scoring } 3 \times 3)}{150} \times 100$ 
This formula has been applied before to quantify blackpoint incidence (Ellis et al. 1996).

Data was analysed using Genstat (Release 13, VSN International Ltd, Lawes Agricultural Trust, Rothamsted, UK). Analysis of variance was applied to each dataset to assess the effects of treatments on grain quality for split-plot designs. The modified Gompertz model (Gooding et al. 2000, 2003) was applied to quantify the decline in moisture content during grain development and maturation $(X, \mathrm{DAA})$ :

moisture content $(\mathrm{g} / \mathrm{kg})=A+C \times \exp [-\exp \{-k \times(X-m)\}]$

where $C$ is initial moisture content, $A$ is final moisture content, $k$ is rate of decline, and $m$ is duration (days) from anthesis to curve inflection, which equated here to $470 \mathrm{~g} / \mathrm{kg}$ moisture content. This inflection point coincides with the end of grain filling. The end of grain filling was termed physiological maturity (Shaw \& Loomis, 1950), but as grains are not physiologically mature at this stage it is potentially misleading and so the term mass maturity was introduced (Ellis \& Pieta Filho, 1992) and is used here.

Grain dry weight at harvest is a function of the rate and duration of grain filling. Grain filling in each treatment was quantified as broken-stick regressions using the FITNONLINEAR directive in Genstat, comprising a linear increase in grain dry weight with duration of development until maximum grain weight was achieved with no change thereafter (Pieta Filho \& Ellis 1991; Egli 1998; Gooding et al. 2003) and quantified by the three variables maximum grain weight (i.e. breakpoint on y-axis), linear rate of grain filling (slope), and the duration (i.e. breakpoint on $\mathrm{x}$-axis) from anthesis until mass maturity. The regressions were fitted separately to each main plot and compared. 


\section{RESULTS}

Anthesis of 50\% of tillers occurred on 8 June 2011 (84 days after sowing) and 18 June 2012 (95 days after sowing). Rainfall and temperature varied between years from anthesis until final harvest (Fig. 1): maximum and minimum temperatures were 21.5 and $9.0{ }^{\circ} \mathrm{C}$ (mean $15.4{ }^{\circ}$ C, Fig. $1 a$ ) with relative humidity extremes of 89.0 and $59.8 \%$ in 2011 and rainfall was unevenly distributed with the maximum rainfall, $59.5 \mathrm{~mm}$, occurring 71 DAA (18 August 2011). In 2012, these respective values were 21.4 and $11.1^{\circ} \mathrm{C}$ (mean $16.5^{\circ} \mathrm{C}$, Fig. $1 b$ ), 90.5 and 59.8\% (Fig. 1b), with the maximum rainfall, $14.2 \mathrm{~mm}$, recorded 3 DAA (21 June 2012). Summer 2011 was wetter, but slightly less humid, and cooler than 2012 and both years were wetter and cooler than the decadal mean (Table 1).

The shelters affected the production environment beyond just rainfall protection. Transmission of PAR through the covers was $84.6 \%$ with $90.2 \%$ direct light transmission. On average, crops under cover were $0.8-0.9{ }^{\circ} \mathrm{C}$ warmer than open controls.

Desiccation patterns matched general expectations for grain development and maturation and were described well by the Gompertz function in 2011 (Fig. 2) and 2012 (Fig. 3), with the inflection point at $470 \mathrm{~g} / \mathrm{kg}$ (Table 2). However, in two of the later-applied treatments where there were very few observations, either an estimate was unreliable $(k, \mathrm{~S} 4$, 2011, Table 2) or the fit was poor (W5, 2012, Fig. 3i). The phase of most rapid desiccation (broadly 30-50 DAA) was more obvious in the warmer and drier 2012, where equilibrium with ambient was approached at about 56 DAA (Fig. 3) compared with 10-20 days later in 2011 (Fig. 2); final moisture contents were lower in 2011. Differences were detected amongst treatments in duration to $200 \mathrm{~g} / \mathrm{kg}$ moisture content in both years but for drying rate in 2011

only (Table 2). Comparisons amongst fitted curves within each year showed only small differences. Not surprisingly, rain shelter throughout the study period resulted in the most rapid loss in moisture and lower final values than open controls (Figs $2 a$ and $3 a$ ). On the 
other hand, although wetting had an immediate effect on moisture content (Fig. 3j), there was little effect on the fitted curves overall (Figs $2 f-j$ and $3 e-i)$.

Grain filling was described well by broken-stick regressions in both years (Figs 4 and 5) with a linear phase of grain filling beginning (by extrapolation) some 10 (2011) to 12 DAA (2012) and at similar rates thereafter in both years' controls (Table 3). The treatments affected final grain dry weight significantly $(P<0.01)$ within each year, heavier on average in 2011 than 2012, and durations to mass maturity in 2011 (only) $(P<0.01$ ), longer on average in 2011 than 2012 (Table 3). The remaining estimates in these relationships did not differ significantly $(P>0.05)$. Hence, neither did the fitted broken-stick relationships differ greatly amongst treatments within each year: shelter throughout the study period or for the first 14 days during the grain-filling phase resulted in lower final grain dry weight - and a more rapid, shorter grain-filling phase - in 2011 (Figs $4 a, b$ ) but not in 2012 (Figs 5a-d); no wetting treatment affected these relationships in either year (Table 3). Final grain dry weight was correlated positively with duration of grain filling within each year (Fig. 6).

In 2011, all aspects of grain quality assessed were affected significantly $(P<0.01$ or $P<0.001)$ by treatments, whereas in 2012 only $\mathrm{N}$ concentration (and so $\mathrm{CP})(P<0.01)$ and blackpoint $(P<0.001)$ were affected (Table 4$)$. Rain shelter in 2011 , especially throughout the entire study period, reduced CP whereas no consistent, nor significant $(P>0.05)$, effect of wetting treatment was detected. In the drier 2012, the effect of rain shelter on CP was very much less, with shelter throughout reducing it significantly $(P<0.05)$ and, as in the previous year; wetting treatments had no clear effect $(P>0.05)$. The two extreme treatments at $49 \pm 7$ days (i.e. S2 and W2) gave the highest CP of all treatments in 2012, but this was not the case in 2011 (i.e. S4 and W4) where treatment at these developmental times both provided estimates lower than the control. 
Sulphur concentration was reduced significantly $(P<0.05)$ by rain shelter in 2011 , being least for shelter throughout and S3 (see below). Ear wetting did not affect S concentration $(P>0.05)$. As a consequence of the above effects on each of $\mathrm{N}$ and $\mathrm{S}$ in 2011 , $\mathrm{N}: \mathrm{S}$ ratios were consistently greater than the control amongst the rain shelter treatments and whilst, on average, they were lower than the control for wetting treatments this was neither consistent nor significant $(P>0.05)$. The greatest effect on $\mathrm{N}: \mathrm{S}$ ratio (and highest value) was detected in S3 (rain shelter in the final $14 \mathrm{~d}$ of grain-filling, Fig. $4 d$ ) where protein content was unaffected by treatment but $\mathrm{S}$ concentration was substantially reduced (Table 4). The non-significant effects of the contrasting treatments on $\mathrm{N}: \mathrm{S}$ ratio in 2012 provided estimates lower than the control in every case. Variation in $\mathrm{N}$ and $\mathrm{S}$ concentrations were each correlated negatively with final mean grain dry weight in 2012 (Fig. 7). No significant correlations were detected between these traits in 2011 .

Hagberg falling number was reduced by all but the last of the rain shelter treatments (S4) and also, but to a lesser extent, by two of the wetting treatments (W1 and W4) in 2011 (Table 4). The treatments did not affect HFN significantly in 2012, but all treatments (shelter and ear wetting) provided estimates greater than the control. The control result for 2012 was also lower than that for 2011.

Estimates of SDS-sedimentation volumes were reduced significantly $(P<0.05)$ in all five rain shelter treatments in 2011. The effect of ear wetting was variable and only significant $(P>0.05)$, a reduction, in one case (W3). Comparison amongst controls and annual means showed greater SDS volumes in 2012 than 2011.

The incidence of blackpoint was greater in 2011 than 2012 and both years provided similar and consistent treatment responses. Blackpoint was increased by wetting treatments and reduced under rain shelter (Table 4). The greatest reduction in the incidence of 
blackpoint occurred with rain shelter throughout in both years and the greatest increase with multiple wettings in 2011 and wetting at 70 DAA (W5) in 2012.

\section{DISCUSSION}

There is no doubt that rainfall, or its absence, can affect wheat grain quality, but the objective of the current paper was to determine whether altering the environment of developing and maturing ears in field-grown crops, and the timing of intervention, could be shown to affect grain quality. The treatments did affect the dynamics of grain filling and desiccation, provided in the former case they were applied before mass maturity. The effects on grain quality were clear and consistent for blackpoint, but far more difficult to discern for the remaining traits with some responses contrary to expectations from known associations between the inter-annual variations of grain quality and weather.

The use of the Gompertz function to quantify the dynamics of grain desiccation (Gooding et al. 2003; Pepler et al. 2005) and of the broken-stick model to quantify the dynamics of grain filling (Sofield et al. 1977; Renwick \& Duffus 1987; Rasyad et al. 1990; Pieta Filho \& Ellis 1991; Ellis et al. 1993; Gooding et al. 2003) were each appropriate here (Figs 2-5). Grain desiccation is typically sigmoidal in form. Grain dry matter accumulation, however, sometimes shows a linear increase with a sharp transition to a plateau (as above), but in other cases the data follows a distinct sigmoidal pattern (Egli 1998, 2004; Wardlaw et al. 2002). We suggest that the suitability of broken-stick models indicates a strong degree of temporal uniformity amongst grain within each treatment in the current small plot study: if grain filling in each individual grain follows a broken-stick model, then high temporal variability in filling amongst individual grains would, inevitably, provide an S-shaped curve for the whole population. 
The rate of grain filling can be affected by the position of grains within ears (Sofield et al. 1977), cultivar (Miralles \& Slafer 1995; Dimmock \& Gooding 2002) and environment (Wheeler et al. 1996; Wardlaw et al. 2002; Gooding et al. 2003; Zahedi \& Jenner 2003). Estimates of grain filling rate were conservative in the current study, being identical for controls between the two years $(1.63 \mathrm{mg} / \mathrm{d})$, notwithstanding the inter-annual variation in environment, and with no significant effect of treatments within either year. Given that the treatments were not imposed until the reproductive phase of development and so canopy dry matter was invariant at the beginning of grain filling, this is compatible with the suggestion of grain filling comprising a consistent daily proportional contribution to harvest index at harvest (Moot et al. 1996; Wheeler et al. 1996).

The effects of both rain shelter and wetting on grain filling duration, and so final grain dry weight, were significant but negligible in 2011 - the only possible temporal consistency in the latter being provided by rain shelter for both 0-56 DAA (C2S) and 0-14 DAA (S1), i.e. soon after anthesis when early cell division determines maximum cell number (Bewley et al. 2013). Although final grain dry weight in 2012 differed significantly amongst treatments, the rate and the duration of grain filling did not. The absence of any significant effect of rain shelter treatments S1-S3 or of wetting treatments on grain filling dynamics in 2012 was not unexpected as they were not provided until after mass maturity, but the increase in final grain dry weight for rain shelter from 0-70 DAA is difficult to explain.

Water shortage during grain filling accelerates leaf senescence and so shortens the grain-filling period (Gooding et al. 2003; Egli 2004). Nevertheless, there is no real conflict with such results from imposing drought, because in the current study it was neither imposed nor relieved deliberately: treatments were targeted at the ears, the site has a high water table, both years were comparatively cool and wet, and run-off from rain shelters infiltrated the soil. Nevertheless, duration of grain filling and final grain dry weight were correlated positively 
within each year. This explained much of the variation amongst treatments, but two sheltered treatments in 2012 (C2S and S2) were outliers showing considerably greater final grain dry weight.

Ellis \& Pieta Filho (1992) reported grain moisture contents at mass maturity of 400$480 \mathrm{~g} / \mathrm{kg}$ (mean $440 \mathrm{~g} / \mathrm{kg}$ ) in four wheat varieties. These estimates (mean of all treatments) were similar in the current work: $474 \mathrm{~g} / \mathrm{kg}$ in 2011 and $443 \mathrm{~g} / \mathrm{kg}$ in 2012 . The latter varied significantly in 2012 (but not in 2011) and control treatments in the 2 years provided near identical estimates $(476-479 \mathrm{~g} / \mathrm{kg})$. As with dry weight, treatment effects on the progress of grain desiccation were somewhat limited. Rain shelter throughout or during maturation drying (C2S, S3-4, 2011; C2S, S1-S3, 2012) resulted in more rapid grain desiccation. In the case of ear wetting, only when the immediate effects were collated in 2012 (designated W) did the period of maturation drying appear to be prolonged. Hence, ear wetting affected grain moisture content only temporarily.

The ear wetting treatment applied in the current work was a simple, crude simulation of (additional) natural rainfall. Rainfall events vary greatly in terms of, for example, duration, intensity, droplet size and velocity, and wind speed as well as volume per unit area. The treatment used in the current study most closely matched an intense, brief summer storm and contrasts with, for instance, continuous drizzle over long periods in terms of moisture penetration within the glumes and delaying grain drying. Although simple and crude, the current authors' previous studies confirmed this experimental approach affected wheat grain moisture and also subsequent seed longevity (Ellis \& Yadav 2016). Wetting had no significant, nor temporally consistent, effects on $\mathrm{N}$ and $\mathrm{S}$ concentrations or SDS volumes and so no direct effect on protein amount or quality. Rain shelter throughout the study period (C2S) reduced all three variables in both years, reducing the end-use value of the crop. This was also the case, to some extent, for 14 day periods of rain shelter in 2011, but not in 2012 . 
This result from rain shelter in 2011 is contrary to reports that water stress applied before the end of grain filling increased N and CP content in wheat (Daniel \& Triboi 2002; Gooding et al. 2003), but the treatments imposed in the current work were more subtle than those in drought studies (see above). Moreover, Gooding et al. (2003) have noted that such conclusions from controlled-environment studies may not be applicable to all field studies. Some field results (Smith \& Gooding 1996; Clarke et al. 2004) have suggested that greater rainfall increases $\mathrm{N}$ concentration, due to increased $\mathrm{N}$ mineralization in certain soils (Gooding \& Davies 1997), but the situation is highly specific to the particular circumstances regarding the amount and timing of rainfall since heavy rain before grain filling can dilute soil $\mathrm{N}$ by increased leaching and the greater vegetative growth of crops (Schlehuber \& Tucker 1959; Hopkins 1968; Powlson et al. 1992). The S concentrations in all five rainfallprotected treatments in 2011 were either at or below the critical value for $\mathrm{S}$ deficiency $(<1.2$ $\mathrm{g} / \mathrm{kg}$ ) in wheat (McGrath et al. 1993), whereas all samples in 2012 provided estimates well above this value, despite the available sulphate in soil in the spring being lower in 2012.

Notwithstanding the limited extent of treatment effects, the negative correlations of each of grain $\mathrm{N}$ and $\mathrm{S}$ concentrations with mean grain dry weight in 2012, only, is compatible with the well-known inverse relationship of protein concentration with yield per unit area (Smith \& Gooding 1999; Cox et al. 1985; Triboi et al. 2006; Gooding et al. 2007). Similarly, the reduction in SDS-volume by rain shelter throughout (C2S) in both years is supported by Gooding et al. (2003) for the effect of reduced moisture availability from just before grain filling in wheat.

All but one (rain shelter from 0-56 DAA (C2S) in 2011) of the 22 treatments provided HFN values above the commercially desired minimum threshold of 250s. Mean estimates across the UK over many years from the AHDB Recommended Lists for 2016/17 provide good HFN values of 303-311s for cvar Tybalt from spring and late-winter sowings, 
respectively (cereals.ahdb.org.uk/varieties.aspx, accessed 26 January 2016); similarly good mean estimates (all treatments) of 306 and 372 s were obtained for HFN in 2011 and 2012, respectively, in the current work and confirm the resilience of this aspect of grain quality in cvar Tybalt. Cool and wet weather during late grain growth and ripening, as occurred in both years, can promote pre-maturity alpha-amylase activity and so reduce HFN (Gale et al. 1983; Gooding et al. 1997; Kondhare et al. 2015). Gooding et al. (2003) reported HFN was increased by drought before the end of grain filling, and high soil moisture was associated with low HFN and so high $\alpha$-amylase activity (Gooding et al. 2003; Gooding 2010). In contrast, every shelter treatment in 2011 reduced HFN below the control and wetting had comparatively little effect. In 2012 the non-significant variation in HFN did provide a substantial, consistent increase in HFN with rain shelter but also, to a lesser extent, in all wetting treatments. The final harvest in 2011 was some $14 \mathrm{~d}$ after shelter treatments ended with a heavy, atypical rainfall event during this period. In 2012, therefore, shelter treatments were provided until the final harvest. Higher $\mathrm{N}$ concentration grain samples can show higher estimates of HFN (Gooding et al. 1987; Kettlewell 1999; Clarke et al. 2004; Kindred et al. 2005). This was detected in the current study in $2011(r=0.623 ; 0.10>P>0.05)$, but not in 2012, and might explain the otherwise apparently contradictory response of HFN to rain shelter in 2011.

In contrast to the preceding grain quality variables, the incidence of blackpoint responded consistently to treatments in both years, and in accordance with results where irrigation increased the incidence and severity of blackpoint (Clarke et al. 2004). It was reduced by protection from rainfall, lower in the drier 2012 than 2011, lowest under shelter for the longest durations (C2S) and increased under almost all wetting treatments. No trend was detected within either the shelter or wetting treatments, however, providing no evidence of temporal variation in the environmental regulation of blackpoint. 
The systematic (i.e. sequential) design with opposite (i.e. wetting vs. shelter) treatments provided little or no clear, consistent evidence of simulated rainfall event effects on wheat grain quality with the single exception of blackpoint. Both years were above average in terms of summer rainfall and so well-suited for blackpoint development. In cool, wet years therefore, it can be concluded that blackpoint is the most sensitive of all wheat grain quality traits investigated to variation in moisture availability around the ears whereby a single additional $25 \mathrm{~mm}$ simulated rainfall event (c. 10-12\% additional 'rain') was sufficient to increase its incidence.

Despite the undoubted and considerable influence of water status from heavy rainfall to drought on, for example, HFN and CP evident from controlled environment studies and national records, demonstrating this experimentally by altering the environment around developing and maturing ears of field-grown crops was more difficult than anticipated from the literature. Gooding et al. (1997) estimated that the HFN of UK wheat crops was reduced by $0.93 \mathrm{~s} / \mathrm{mm}$ August rainfall, but not detectably so by rainfall in earlier months. The 2011 treatments ended in July and so all treatments received the same (high) August rainfall, but nevertheless HFN varied significantly. In contrast, and paradoxically, the non-significant variation in 2012 was compatible in large part with Gooding et al. (1997) in terms of both the direction and magnitude of the effect of August rainfall. Comparing the extreme treatments (thus ignoring the open control's unusually low estimate), the actual (mean of all $25 \mathrm{~mm}$ ear wetting treatments) and expected reductions in $\mathrm{HFN}$ from C2S were 43 (c. $0.7 \mathrm{~s} / \mathrm{mm}$ August rainfall) and 59 s, i.e. about three quarters of the response suggested by Gooding et al. (1997). This is good agreement given that their data would have included what might be considered the direct effect of rainfall on ears, as investigated in the current paper, together with that via the soil and crop, and also of harvest delays (and so a longer period for germination sensu strictu to be promoted) as a result of wetter seasons. 
In the current investigation, and as occurs in wheat production, the passage of time between a rainfall event and subsequent harvest at maturity provided an interregnum during which grain quality might change. Delaying harvest until 7 days after ear wetting provided a $51 \mathrm{~s}$ improvement in HFN (W and W5 at 70 and 77 DAA, respectively). The possible improvement in HFN with re-drying in planta requires further investigation since the damage to post-harvest seed longevity in wheat from rainfall can be reversed with re-drying in planta (Ellis \& Yadav 2016). Monitoring the dynamics of grain filling and desiccation was successful. Hence, quantifying the dynamics of grain quality development (e.g. HFN) might enable both the immediate effect of environment and subsequent change, such as the possible reversal of damage to HFN noted above, until harvest to be captured in future investigations.

In conclusion, blackpoint was the most sensitive grain quality trait to rain incident on developing and maturing ears but it was not possible to identify any clear temporal pattern of sensitivity to rain for blackpoint or any of the other grain quality traits investigated in the current field study. Indeed, other than blackpoint, grain quality was comparatively resilient to rain incident upon developing and maturing ears in cvar Tybalt.

The Commonwealth Scholarship Commission provided a research studentship to GY (INCS2010-170). We thank Caroline Hadley and Richard Casebow for their considerable help.

\section{REFERENCES}

Anonymous (1985). The Blackpoint Index of Wheat. A Guide to its Calculation. Plant Protection Centre Bulletin. Lincoln, New Zealand: Ministry of Agriculture and Fisheries.

Association Of Official Analytical Chemists International (2005). Official Methods of Analysis of AOAC International, $18^{\text {th }} \mathrm{ed}$. Gaithersburg, MD, USA: AOAC International. 
Bewley, J. D., Bradford, K., Hilhorst, H. W. M. \& Nonogaki, H. (2013). Seeds: Physiology of Development, Germination and Dormancy, 3rd Edition. New York: Springer-Verlag.

Clarke, M. P., Gooding, M. J. \& Jones, S. A. (2004). The effects of irrigation, nitrogen fertilizer and grain size on Hagberg falling number, specific weight and blackpoint of winter wheat. Journal of the Science of Food and Agriculture 84, 227-236.

Cox, M. C., Qualset, C. O. \& Rains, D. W. (1985). Genetic variation for nitrogen assimilation and translocation in wheat. I. Dry matter and nitrogen accumulation. Crop Science 25, 430-435.

Cromey, M. G. \& Mulholland, R. I. (1988). Blackpoint of wheat: fungal associations, cultivar susceptibility, and effects on grain weight and germination. New Zealand Journal of Agricultural Research 31, 51-56.

DAniEl, C. \& TriBOI, E. (2002). Changes in wheat protein aggregation during grain development: effects of temperatures and water stress. European Journal of Agronomy 16, 1-12.

DimMock, J. P. R. E. \& GoOdinG, M. J. (2002). The effects of fungicides on rate and duration of grain filling in winter wheat in relationship to maintenance of flag leaf green area. Journal of Agricultural Science, Cambridge 138, 1-16.

EGLI, D. B. (1998). Seed Biology and the Yield of Grain Crops. Wallingford, UK: CABI.

EGLI, D. B. (2004). Seed-fill duration and yield of grain crops. Advances in Agronomy 83, 243-279. 
Ellis, R. H., Hong, T. D. \& JACKSON, M. T. (1993). Seed production environment, time of harvest, and the potential longevity of seeds of three cultivars of rice (Oryza sativa L.). Annals of Botany 72, 583-590.

Ellis, R. H. \& PIETA-FILHO, C. (1992). The development of seed quality in spring and winter cultivars of barley and wheat. Seed Science Research 2, 9-15.

ELLIS, R. H. \& YADAV, G. (2016). Effect of simulated rainfall during wheat seed development and maturation on subsequent seed longevity is reversible. Seed Science Research 26, $67-76$.

Ellis, S.A., Gooding, M.J. \& Thompson, A.J. (1996). Factors influencing the relative susceptibility of wheat cultivars (Triticum aestivum L.) to blackpoint. Crop Protection 15, 69-76.

Fullington, J. G., Miskelly, D. M., Wrigley, C. W. \& Kasarda, D. D. (1987). Qualityrelated endosperm proteins in sulfur-deficient and normal wheat grain. Journal of Cereal Science 5, 233-245.

Gale, M. D., Law, C. N., Chojecki, A. J. \& Kempton, R. A. (1983). Genetic control of $\alpha-$ amylase production in wheat. Theoretical and Applied Genetics 64, 309-316.

Gooding, M. J. (2010). The effects of growth environment and agronomy on grain quality. In Cereal Grains: Assessing and Managing Quality (Eds C. Wrigley \& I. L. Batey), pp. 393-412. Oxford, UK: Woodhead Publishing Ltd.

Gooding, M. J. \& DAVIES, W. P. (1997). Wheat Production and Utilization: Systems, Quality and the Environment. Wallingford, UK: CABI. 
Gooding, M. J., Dimmock, J. P. R. E., France, J. \& Jones, S. A. (2000). Green leaf area decline of wheat flag leaves: the influence of fungicides and relationships with mean grain weight and grain yield. Annals of Applied Biology 136, 77-84.

Gooding, M. J., ElLis, R. H., SHEwRY, P. R. \& SchOFIELD, J. D. (2003). Effects of restricted water availability and increased temperature on the grain filling, drying and quality of winter wheat. Journal of Cereal Science 37, 295-309.

Gooding, M. J., Kasyanova, E., Ruske, R., Hauggaard-Nielsen, H., Jensen, E. S., Dahlmann, C., Von Fragstein, P., Dibet, A., Corre-Hellou, G., Crozat, Y., Pristeri, A., Romeo, M., Monti, M. \& LAunay, M. (2007). Intercropping with pulses to concentrate nitrogen and sulphur in wheat. Journal of Agricultural Science, Cambridge $145,469-479$.

Gooding, M. J., Kettlewell, P. S., Davies, W. P. \& Hocking, T. J. (1987). Do fungicides reduce Hagberg falling number of wheat by maintaining grain moisture content during grain development. Aspects of Applied Biology 15, 413-416.

Gooding, M. J., Smith, G., Davies, W. P. \& Kettlewell, P. S. (1997). The use of residual maximum likelihood to model grain quality characters of wheat with variety, climatic and nitrogen fertilizer effects. Journal of Agricultural Science, Cambridge 128, 135-142.

Hanson, E. W. \& Christensen, J. J. (1953). The Black Point Disease of Wheat in the United States. Technical Bulletin, 206. St. Paul, MN, USA: Agricultural Experiment Station, university of Minnesota.

Hopkins, J. W. (1968). Protein content of western Canadian hard red spring wheat in relationship to some environmental factors. Agricultural Meteorology 5, 411-431. 
Hulme, M., Osborn, T. J. \& Johns, T. C. (1998). Precipitation sensitivity to global warming: Comparison of observations with HadCM2 simulations. Geophysical Research Letters 25, 3379-3382.

IPCC (2014) Climate Change 2014: Synthesis Report. Contribution of Working Groups I, II and III to the Fifth Assessment Report of the Intergovernmental Panel on Climate Change (Eds Core Writing Team, R. K. Pachauri \& L. A. Meyer). Geneva, Switzerland: The Intergovernmental Panel on Climate Change.

International Seed Testing Association (2011). International Rules for Seed Testing. Edition 2011. Zurich, Switzerland: The International Seed Testing Association.

Jones, P. D. \& Hulme, M. (1996). Calculating regional climatic time series for temperature and precipitation: methods and illustrations. International Journal of Climatology 16, $361-377$.

Kettlewell, P. S. (1999). The response of alpha-amylase activity during wheat grain development to nitrogen fertiliser. Annals of Applied Biology 134, 241-249.

Kindred, D. R., Gooding, M. J. \& ElLis, R. H. (2005). Nitrogen fertilizer and seed rate effects on Hagberg failing number of hybrid wheats and their parents are associated with alpha-amylase activity, grain cavity size and dormancy. Journal of the Science of Food and Agriculture 85, 727-742.

Klein Tank, A. M. G., WijngaArd, J. B., Können, G. P., Böhm, R., Demarée, G., Gocheva, A., Mileta, M., Pashiardis, S., Hejkrlik, L., Kern-Hansen, C., Heino, R., Bessemoulin, P., Müller-Westermeier, G., Tzanakou, M., Szalai, S., PÁlsdótTir, T., Fitzgerald, D., Rubin, S., Capaldo, M., Maugeri, M., Leitass, A., Bukantis, A., Aberfeld, R., Van Engelen, A. F. V., Forland, E., Mietus, M., Coelho, F., Mares, 
C., Razuvaev, V., Nieplova, E., Cegnar, T., LóPez, J. A., Dahlström, B., Moberg, A., Kirchhofer, W., Ceylan, A., Pachaliuk, O., Alexander, L.V. \& Petrovic, P. (2002). Daily dataset of 20th-century surface air temperature and precipitation series for the European Climate Assessment. International Journal of Climatology 22, 1441-1453.

Kondhare, K. R., Farrell, A. D., Kettlewell, P. S., Hedden, P. \& Monaghan, J. M. (2015). Pre-maturity $\alpha$-amylase in wheat: The role of abscisic acid and gibberellins. Journal of Cereal Science 63, 95-108.

LORENZ, K. (1986). Effects of blackpoint on grain composition and baking quality of New Zealand wheat. New Zealand Journal of Agricultural Research 29, 711-718.

Lunn, G. D., Kettlewell, P. S., Major, B. J. \& Scott, R. K. (2001). Effects of pericarp alpha-amylase activity on wheat (Triticum aestivum) Hagberg falling number. Annals of Applied Biology 138, 207-214.

McGrath, J. M, Jancso, M. M. \& Pichersky, E. (1993). Duplicate sequences with a similarity to expressed genes in the genome of Arabidopsis thaliana. Theoretical and Applied Genetics 86, 880-888.

Miralles, D. J. \& Slafer, G. A. (1995). Individual grain weight responses to genetic reduction in culm length in wheat as affected by source-sink manipulations. Field Crops Research 43, 55-66.

Moot, D. J., Jamieson, P. D., Henderson, A. L., Ford, M. A. \& Porter, J. R. (1996). Rate of change in harvest index during grain filling of wheat. Journal of Agricultural Science, Cambridge 126, 387-395. 
Nicolas, M. E., Gleadow, R. M. \& Dalling, M. J. (1984). Effects of drought and high temperature on grain growth in wheat. Australian Journal of Plant Physiology 11, 553566.

Peña, R. J., Trethowan, R., Pfeiffer, W. H. \& Van Ginkel, M. (2002). Quality (end-use) improvement in wheat: compositional, genetic, and environmental factors. Journal of Crop Production 5, 1-37.

Pepler, S., Gooding, M. J., Ford, K. E. \& Ellis, R. H. (2005). A temporal limit to the association between flag leaf life extension by fungicides and wheat yields. European Journal of Agronomy 22, 363-373.

PIETA FilHo, C. \& ElLIS, R. H. (1991). The development of seed quality in spring barley in four environments. I. Germination and longevity. Seed Science Research 1, 163-177.

Powlson, D. S., Hart, P., Poulton, P. B. S., Johnston, A. E. \& Jenkinson, D. S. (1992). Influence of soil type, crop management and weather on the recovery of $15 \mathrm{~N}$-labelled fertilizer applied to winter wheat in spring. Journal of Agricultural Science, Cambridge 118, $83-100$.

Rasyad, A., VAnsanford, D. A. \& TeKrony, D. M. (1990). Changes in seed viability and vigor during wheat seed maturation. Seed Science and Technology 18, 259-267.

RenwiCK, F. \& Duffus, C. M. (1987). Factors affecting dry weight accumulation in developing barley endosperm. Physiologia Plantarum 69, 141-146.

SCHLEHUBER, A. M. \& TUCKER, B. B. (1959). Factors affecting the protein content of wheat. Cereal Science Today 4, 240-242. 
SHAW, R. H. \& LOOMIS, W. E. (1950). Bases for the prediction of corn yields. Plant Phvsiology 25, 225-244.

Smith, G. P. \& Gooding, M. J. (1996). Relationships of wheat quality with climate and nitrogen application in regions of England (1974-1993). Annals of Applied Biology 129, $97-108$.

Smith, G. P. \& Gooding, M. J. (1999). Models of wheat grain quality considering climate, cultivar and nitrogen effects. Agricultural and Forest Meteorology 94, 159-170.

Sofield, I., Evans, L. T., CoOK, M. G. \& WARdlaw, I. F. (1977). Factors influencing the rate and duration of grain filling in wheat. Australian Journal of Plant Physiology 4, 785-797.

Triboi, E., Martre, P., Girousse, C., Ravel, C. \& Triboi-Blondel, A. M. (2006). Unravelling environmental and genetic relationships between grain yield and nitrogen concentration for wheat. European Journal of Agronomy 25, 108-118.

Wardlaw, I. F., Blumenthal, C., Larroque, O. \& Wrigley, C. W. (2002). Contrasting effects of chronic heat stress and heat shock on kernel weight and flour quality in wheat. Functional Plant Biology 29, 25-34.

Wheeler, T. R., Hong, T. D., Ellis, R. H., Batts, G. R., Morison, J. I. L. \& Hadley, P. (1996). The duration and rate of grain growth, and harvest index, of wheat (Triticum aestivum L) in response to temperature and $\mathrm{CO}_{2}$. Journal of Experimental Botany 47, 623-630.

WILLIAMSON, P. M. (1997). Black point of wheat: in vitro production of symptoms, enzymes involved, and association with Alternaria alternata. Australian Journal of Agricultural Research 48, 13-20. 
ZAHEDI, M. \& JENNER, C. F. (2003). Analysis of effects in wheat of high temperature on grain filling attributes estimated from mathematical models of grain filling. Journal of Agricultural Science, Cambridge 141, 203-212.

ZHAO, F. J., HAWKeSFORD, M. J. \& MCGRATH, S. P. (1999). Sulphur assimilation and effects on yield and quality of wheat. Journal of Cereal Science 30, 1-17. 
Table 1. Mean monthly rainfall and temperature for June-August 2011 and 2012 and decadal means (2001-10), Crop Research Unit, Sonning

\begin{tabular}{l|ccc|ccc}
\hline & Rainfall $(\mathbf{m m})$ & & \multicolumn{3}{|c}{ Temperature $\left({ }^{\circ} \mathbf{C}\right)$} \\
& $\mathbf{2 0 0 1 - 1 0}$ & $\mathbf{2 0 1 1}(\mathbf{r h}) *$ & $\mathbf{2 0 1 2}(\mathbf{r h})$ & $\mathbf{2 0 0 1 - 1 0}$ & $\mathbf{2 0 1 1}$ & $\mathbf{2 0 1 2}$ \\
\hline June & 39.0 & $89.8(73.8)$ & $104.0(77.3)$ & 15.9 & 14.2 & 14.1 \\
July & 56.6 & $40.0(70.5)$ & $72.2(76.1)$ & 17.6 & 15.8 & 16.1 \\
August & 61.8 & $125.2(74.1)$ & $38.4(73.3)$ & 17.4 & 15.9 & 17.3 \\
Mean & 52.5 & $85.0(72.8)$ & $71.5(75.6)$ & 16.9 & 15.3 & 15.9 \\
\hline Total & 157.4 & 255.0 & 214.6 & & & \\
\hline
\end{tabular}

$*_{\mathrm{rh}}=$ relative humidity $(\%)$ 
Table 2. Effect of different rain shelter or ear wetting treatments on grain drying of wheat cvar Tybalt (2011 and 2012) as quantified by the modified Gompertz model

\begin{tabular}{|c|c|c|c|c|}
\hline Treatment & $\begin{array}{l}\text { Duration to } 200 \\
\text { g/kg } \\
\text { moisture content } \\
\text { (DAA) }\end{array}$ & $\begin{array}{l}\text { Duration to } 470 \mathrm{~g} / \mathrm{kg} \\
\text { moisture content } \\
\text { (Gompertz } m, \text { DAA) }\end{array}$ & $\begin{array}{l}\text { Moisture content } \\
(\mathrm{g} / \mathrm{kg}) \text { at mass } \\
\text { maturity }\end{array}$ & $\begin{array}{l}\text { Drying rate } \\
\text { (Gompertz } k \text {, } \\
\text { per day) }\end{array}$ \\
\hline \multicolumn{5}{|l|}{2011} \\
\hline Control (C1O) & 70.0 & 46.5 & 476 & -0.034 \\
\hline C2S (Shelter 0-56 DAA) & 62.0 & 43.5 & 489 & -0.058 \\
\hline S1 (Shelter 0-14 DAA) & 72.5 & 44.0 & 461 & -0.053 \\
\hline S2 (Shelter 14-28 DAA) & 72.0 & 46.0 & 471 & -0.037 \\
\hline S3 (Shelter 28-42 DAA) & 71.0 & 45.0 & 506 & -0.034 \\
\hline S4 (Shelter 42-56 DAA) & 69.0 & 45.5 & 475 & -0.002 \\
\hline W1 (Wetting 7 DAA) & 72.5 & 45.0 & 476 & -0.038 \\
\hline W2 (Wetting 21 DAA) & 71.5 & 46.5 & 458 & -0.042 \\
\hline W3 (Wetting 35 DAA) & 70.5 & 48.0 & 480 & -0.051 \\
\hline W4 (Wetting 49 DAA) & 71.5 & 48.5 & 430 & -0.099 \\
\hline W5 (Wetting 7+21+35+49 DAA) & 76.0 & 47.0 & 490 & -0.042 \\
\hline $\mathbf{L S D}_{0.05}$ & 4.61 & 1.86 & 70.2 & 0.02 \\
\hline$P$ & $<0.01$ & $<0.01$ & $N S$ & $\leq 0.01$ \\
\hline 2012 & & & & \\
\hline
\end{tabular}




\begin{tabular}{lcccc} 
Control (C1O) & 74.0 & 42.0 & 479 & -0.069 \\
C2S (Shelter 0-70 DAA) & 56.5 & 40.0 & 389 & -0.059 \\
S1 (Shelter 42-70 DAA) & 58.0 & 41.5 & 459 & -0.065 \\
S2 (Shelter 42-56 DAA) & 74.0 & 41.5 & 354 & -0.077 \\
S3 (Shelter 56-70 DAA) & 59.0 & 42.0 & 432 & -0.062 \\
W1 (Wetting 42 DAA) & 74.0 & 42.5 & 507 & -0.064 \\
W2 (Wetting 49 DAA) & 74.0 & 41.5 & 470 & -0.074 \\
W3 (Wetting 56 DAA) & 74.0 & 42.0 & 429 & -0.069 \\
W4 (Wetting 63 DAA) & 74.0 & 42.0 & 488 & -0.070 \\
W5 (Wetting 70 DAA) & 74.0 & 42.0 & 439 & -0.071 \\
W (30 mins after wetting) & 74.0 & 43.0 & 431 & -0.065 \\
LSD & 1.49 & 0.95 & 77.5 & 0.01 \\
$\boldsymbol{P}$ & $\leq 0.001$ & $<0.01$ & <. & $<0.05$ \\
\hline
\end{tabular}

NS, not significant 
Table 3. Effect of different rain shelter or ear wetting treatments on grain filling of wheat cvar Tybalt (2011and 2012 as quantified by broken-stick regressions

\begin{tabular}{|c|c|c|c|}
\hline Treatment & $\begin{array}{l}\text { Rate of } \\
\text { grain filling } \\
\text { (mg/day) }\end{array}$ & $\begin{array}{l}\text { Estimated duration } \\
\text { to mass maturity } \\
\text { (DAA) }\end{array}$ & $\begin{array}{l}\text { Final grain } \\
\text { dry weight } \\
\text { (mg) }\end{array}$ \\
\hline \multicolumn{4}{|l|}{2011} \\
\hline Control (C1O) & 1.63 & 46.3 & 60.0 \\
\hline C2S (Shelter 0-56 DAA) & 1.76 & 41.8 & 58.6 \\
\hline S1 (Shelter 0-14 DAA) & 1.56 & 46.1 & 58.4 \\
\hline S2 (Shelter 14-28 DAA) & 1.64 & 46.7 & 61.5 \\
\hline S3 (Shelter 28-42 DAA) & 1.92 & 43.6 & 59.7 \\
\hline S4 (Shelter 42-56 DAA) & 1.74 & 46.3 & 61.7 \\
\hline W1 (Wetting 7 DAA) & 1.61 & 45.8 & 61.0 \\
\hline W2 (Wetting 21 DAA) & 1.52 & 48.3 & 60.8 \\
\hline W3 (Wetting 35 DAA) & 1.63 & 48.3 & 61.3 \\
\hline W4 (Wetting 49 DAA) & 1.62 & 46.6 & 60.2 \\
\hline W5 (Wetting 7+21+35+49 DAA) & 1.53 & 46.8 & 58.3 \\
\hline $\mathbf{L S D}_{0.05}$ & 0.28 & 2.17 & 1.55 \\
\hline $\boldsymbol{P}$ & $N S$ & $<0.01$ & $<0.01$ \\
\hline \multicolumn{4}{|l|}{2012} \\
\hline Control (C1O) & 1.63 & 42.8 & 49.4 \\
\hline C2S (Shelter 0-70 DAA) & 1.75 & 45.6 & 59.2 \\
\hline S1 (Shelter 42-70 DAA) & 1.63 & 42.8 & 49.5 \\
\hline S2 (Shelter 42-56 DAA) & 1.42 & 48.5 & 53.1 \\
\hline S3 (Shelter 56-70 DAA) & 1.52 & 45.3 & 51.2 \\
\hline
\end{tabular}




\begin{tabular}{lccc} 
W1 (Wetting 42 DAA) & 1.62 & 41.8 & 47.7 \\
W2 (Wetting 49 DAA) & 1.63 & 42.3 & 48.7 \\
W3 (Wetting 56 DAA) & 1.52 & 44.6 & 50.1 \\
W4 (Wetting 63 DAA) & 1.63 & 42.3 & 48.6 \\
W5 (Wetting 70 DAA) & 1.52 & 44.6 & 50.2 \\
W (30 mins after wetting) & 1.43 & 47.1 & 51.1 \\
LSD 0.05 & 0.26 & 4.92 & 3.56 \\
$\boldsymbol{P}$ & $N S$ & $N S$ & $<0.01$ \\
\hline NS, not significant & & &
\end{tabular}


Table 4. Effect of different rain shelter or ear wetting treatments on grain quality of wheat cvar Tybalt (2011 and 2012) at harvest maturity. Samples were harvested 74 DAA (2011) or 70 DAA (2012), except W5 (2012) where it was 77 DAA (7 d after wetting) and W is the sample harvested 30 min after wetting at 70 DAA

\begin{tabular}{lccccccc}
\hline \multicolumn{1}{c}{ Treatment } & $\begin{array}{c}\text { Protein } \\
(\mathbf{g} / \mathbf{k g})\end{array}$ & $\begin{array}{c}\text { Nitrogen } \\
(\mathbf{g} / \mathbf{k g})\end{array}$ & $\begin{array}{c}\text { Sulphur } \\
(\mathbf{g} / \mathbf{k g})\end{array}$ & $\mathbf{N : S}$ & $\begin{array}{c}\text { HFN } \\
(\mathbf{s})\end{array}$ & $\begin{array}{c}\text { SDS } \\
(\mathbf{m l})\end{array}$ & $\begin{array}{c}\text { Black point } \\
(\boldsymbol{\%})\end{array}$ \\
\hline Co11 & & & & & & & \\
\hline Control 2S & 143 & 25.1 & 1.4 & 18.6 & 346 & 72.5 & 22 \\
S1 (0-14 DAA) & 119 & 20.8 & 1.0 & 20.6 & 234 & 59.0 & 8 \\
S2 (14-28 DAA) & 140 & 24.6 & 1.2 & 20.2 & 291 & 61.5 & 12 \\
S3 (28-42 DAA) & 135 & 23.8 & 1.2 & 19.4 & 259 & 56.5 & 18 \\
S4 (42-56 DAA) & 142 & 25.0 & 1.0 & 25.7 & 257 & 51.0 & 13 \\
W1 (7 DAA) & 134 & 23.5 & 1.1 & 21.4 & 338 & 57.0 & 21 \\
W2 (21 DAA) & 143 & 25.1 & 1.4 & 18.5 & 315 & 72.5 & 28 \\
W3 (35 DAA) & 138 & 24.3 & 1.4 & 16.9 & 333 & 77.0 & 29 \\
W4 (49 DAA) & 141 & 24.8 & 1.3 & 19.3 & 335 & 61.0 & 23 \\
W5 (Wetting 7+21+35+49 DAA) & 148 & 26.0 & 1.5 & 17.2 & 345 & 81.0 & 29 \\
LSD & 137 & 24.0 & 1.4 & 17.1 & 315 & 77.5 & 25 \\
$\boldsymbol{P}$ & 05.8 & 1.0 & 0.2 & 2.7 & 27.8 & 10.3 & 9.7 \\
& $<0.001$ & $<0.001$ & $<0.01$ & $<0.001$ & $<0.001$ & $<0.001$ & $<0.01$
\end{tabular}




\begin{tabular}{lccccccc} 
Control 1O & 151 & 26.5 & 1.5 & 19.6 & 288 & 82.5 & 11 \\
Control 2S & 141 & 24.8 & 1.6 & 16.2 & 403 & 78.5 & 5 \\
S1 (42-70 DAA) & 147 & 25.7 & 1.7 & 15.3 & 401 & 79.5 & 8 \\
S2 (42-56 DAA) & 161 & 28.2 & 1.7 & 16.5 & 459 & 82.5 & 9 \\
S3 (56-70 DAA) & 147 & 25.7 & 1.7 & 15.6 & 384 & 81.0 & 9 \\
W1 (42 DAA) & 156 & 27.3 & 1.8 & 15.0 & 309 & 87.0 & 14 \\
W2 (49 DAA) & 160 & 28.1 & 1.9 & 15.1 & 347 & 81.0 & 12 \\
W3 (56 DAA) & 148 & 26.0 & 1.8 & 14.4 & 387 & 80.5 & 11 \\
W4 (63 DAA) & 158 & 27.8 & 1.9 & 15.0 & 374 & 83.0 & 14 \\
W5 (70 DAA) & 148 & 26.0 & 1.8 & 14.8 & 396 & 82.0 & 15 \\
W (30 mins after wetting) & 148 & 25.9 & 1.8 & 14.5 & 345 & 81.0 & 13 \\
LSD 0.05 & 08.4 & 1.5 & 0.4 & 4.4 & 101 & 6.6 & 2.5 \\
$\boldsymbol{P}$ & $<0.01$ & $<0.01$ & $N S$ & $N S$ & $N S$ & $N S$ & $<0.001$ \\
\hline
\end{tabular}

NS, not significant 


\section{FIGURE CAPTIONS}

Fig. 1. Mean daily temperature $\left({ }^{\circ} \mathrm{C},-\right)$, rainfall ( $\mathrm{mm}$, solid bars) and relative humidity $(\%$, ------) of the experimental site during the period of treatment and until final harvest in 2011 (a) and $2012(b)$, Crop Research Unit, Sonning.

Fig. 2. Relationship during grain filling and maturation between grain moisture content (\% fresh weight basis; $\mathrm{x} 10$ for $\mathrm{g} / \mathrm{kg}$ ) and period from $50 \%$ anthesis of wheat cvar Tybalt in 2011, growing under different rain shelter [C2S $(a), \mathrm{S} 1(b), \mathrm{S} 2(c), \mathrm{S} 3(d)$ and S4 (e) (--- $\bigcirc---)]$ or ear wetting treatments [W5 (multiple wettings) $(f), \mathrm{W} 1(g), \mathrm{W} 2(h), \mathrm{W} 3(i)$ and W4 $(j)\left(---\mathrm{O}_{--}\right.$ -)] compared with control (C1O,-- $)$. The Gompertz curves fitted are quantified in Table 2.

Fig. 3. Relationship during grain filling and maturation between grain moisture content (\% fresh weight basis; $\mathrm{x} 10$ for $\mathrm{g} / \mathrm{kg}$ ) and period from 50\% anthesis of wheat cvar Tybalt in 2012 under different rain shelter [C2S $(a), \mathrm{S} 1(b), \mathrm{S} 2(c)$ and S3 $(d)$ (---○---)]or ear wetting treatments [W1 $(e), \mathrm{W} 2(f), \mathrm{W} 3(g), \mathrm{W} 4(h) \mathrm{W} 5(i)$ and W $(30$ min after each wetting) (--- $\square--$ -)] compared with control (C1O,- - The results and fitted curves for W1-5 include those for samples taken immediately before ear wetting, but exclude samples harvested $30 \mathrm{~min}$ afterwards. The latter are presented collectively in W (j). The Gompertz curves fitted are quantified in Table 2.

Fig. 4. Relationship during grain filling and maturation drying between mean grain dry weight (mg) with period from 50\% anthesis of wheat cvar Tybalt in 2011 under different rain shelter [C2S $(a), \mathrm{S} 1(b), \mathrm{S} 2(c), \mathrm{S} 3(d)$ and S4 $(e)(---\bigcirc---)]$ or ear wetting treatments [W5 (multiple wettings) $(f), \mathrm{W} 1(g), \mathrm{W} 2(h), \mathrm{W} 3(i)$ and W4 $(j)(---\bigcirc---)]$ compared with control $(\mathrm{C} 1 \mathrm{O},--)$. The broken-stick relationships fitted are quantified in Table 3. 
Fig. 5. Relationship during grain filling and maturation drying between mean grain dry weight (mg) and period from 50\% anthesis of wheat cvar Tybalt in 2012 under different rain shelter [C2S $(a), \mathrm{S} 1(b)$ and S2 $(c), \mathrm{S} 3(d)(---\bigcirc--)]$ or ear wetting treatments [W1 $(e), \mathrm{W} 2(f)$, W3 $(g)$, W4 $(h)$, W5 $(i)$ and W (30 min after each wetting) $(j)$ (---○---)] compared with control $(\mathrm{C} 1 \mathrm{O},--)$. The results and fitted relationships for W1-5 include those for samples taken immediately before ear wetting, but exclude samples harvested $30 \mathrm{~min}$ afterwards. The latter are presented collectively in $\mathrm{W}(j)$. The broken-stick relationships fitted are quantified in Table 3.

Fig. 6. Correlation between final grain dry weight $(\mathrm{mg})$ and duration from anthesis to maximum grain weight (days) in $(a) 2011(r=0.48 ; P<0.01)$ and $(b) 2012(r=0.61 ; P<0.01)$ for sheltered ( $\boldsymbol{\square})$, ear wetting ( $\mathbf{\Delta})$ and control treatments $(\boldsymbol{O})$ in wheat cvar Tybalt.

Fig. 7. Correlation of mean grain dry weight $(\mathrm{mg})$ with $(a)$ nitrogen $(\% ; \mathrm{x} 10$ for $\mathrm{g} / \mathrm{kg})(r=-$ $0.76 ; P<0.001)$ and $(b)$ sulphur $(\% ; \mathrm{x} 10$ for $\mathrm{g} / \mathrm{kg})(r=-0.36 ; P<0.05)$ concentration of grains of wheat cvar Tybalt in 2012. 

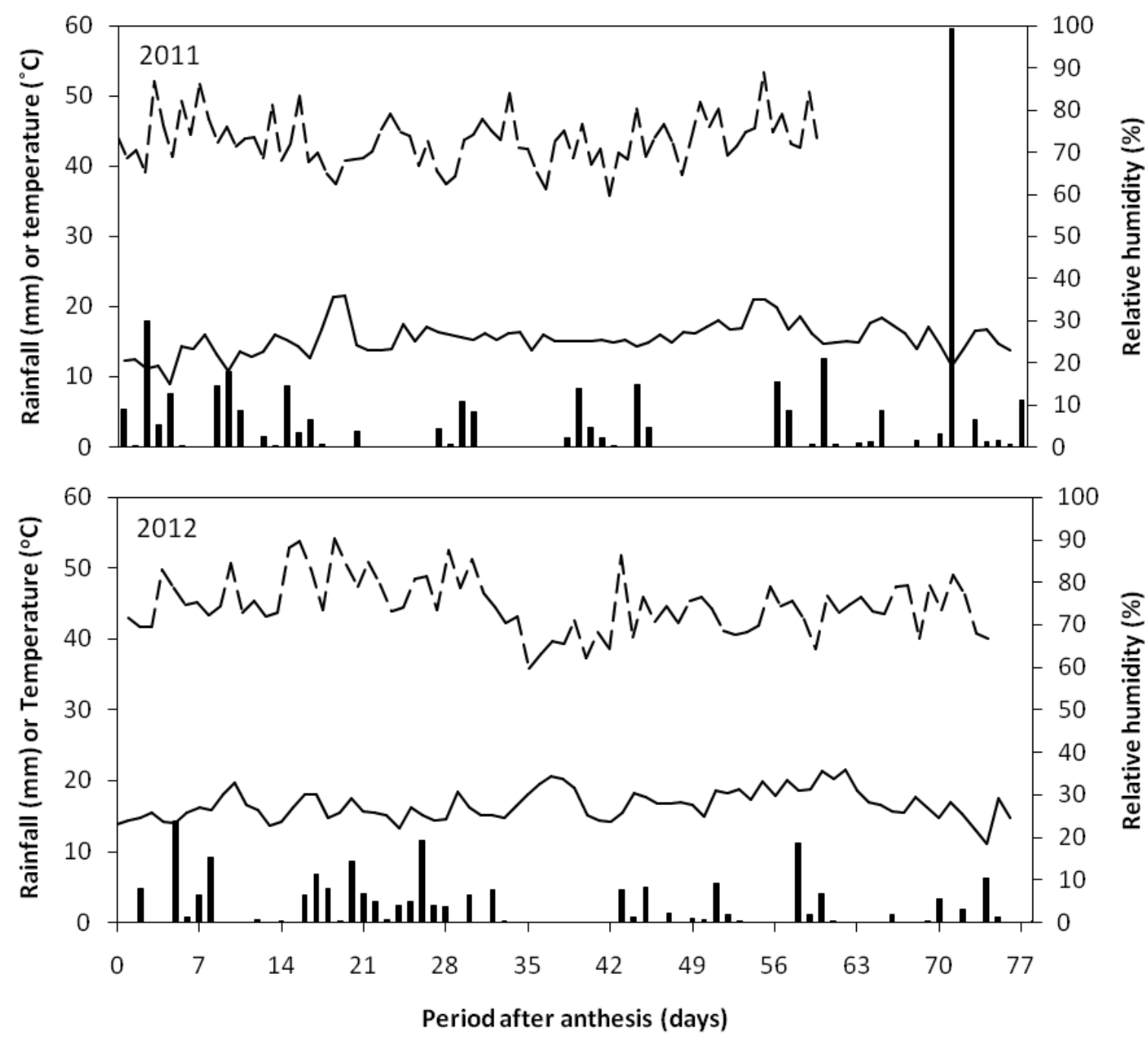

Fig. 1. 

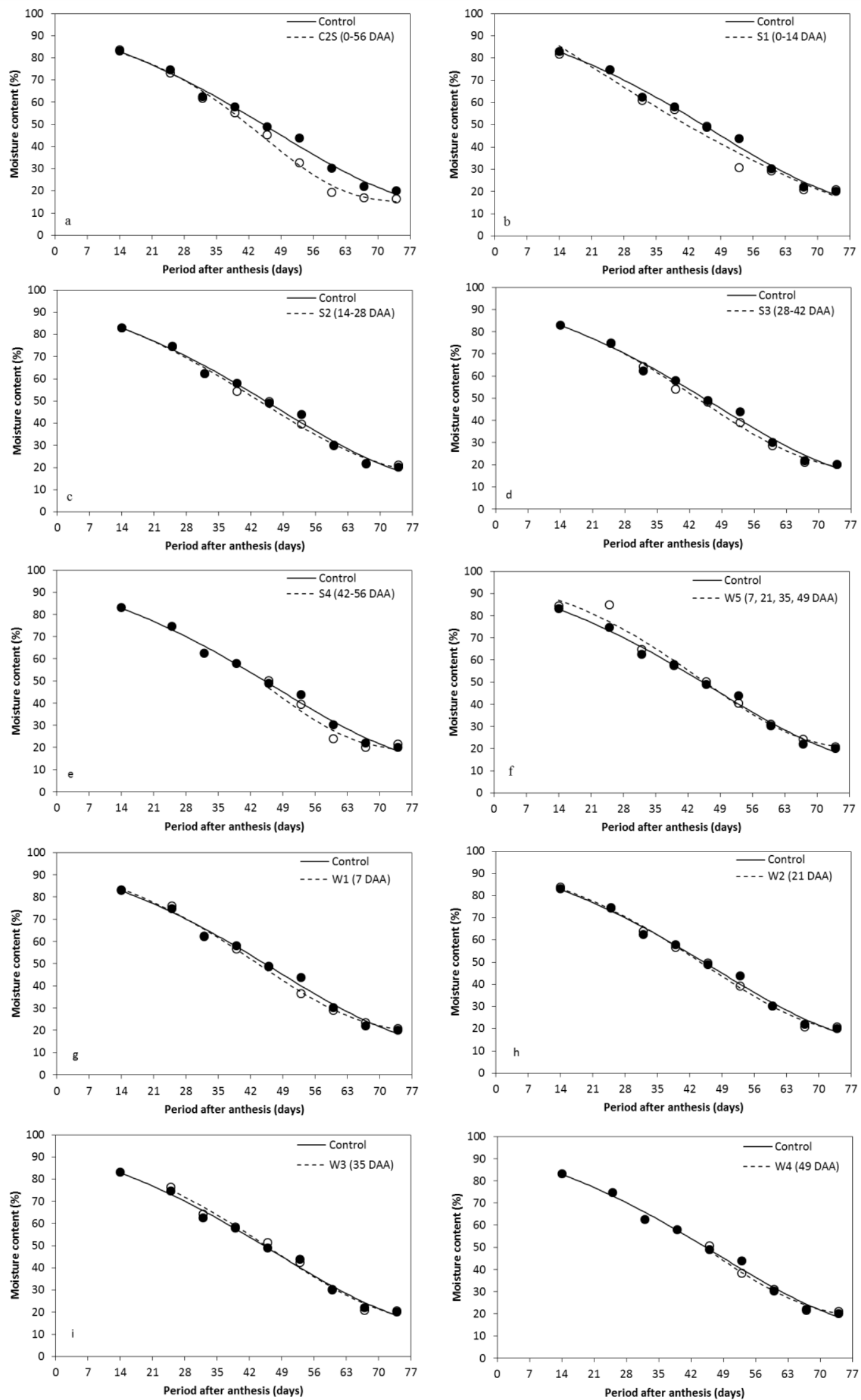

Fig. 2. 

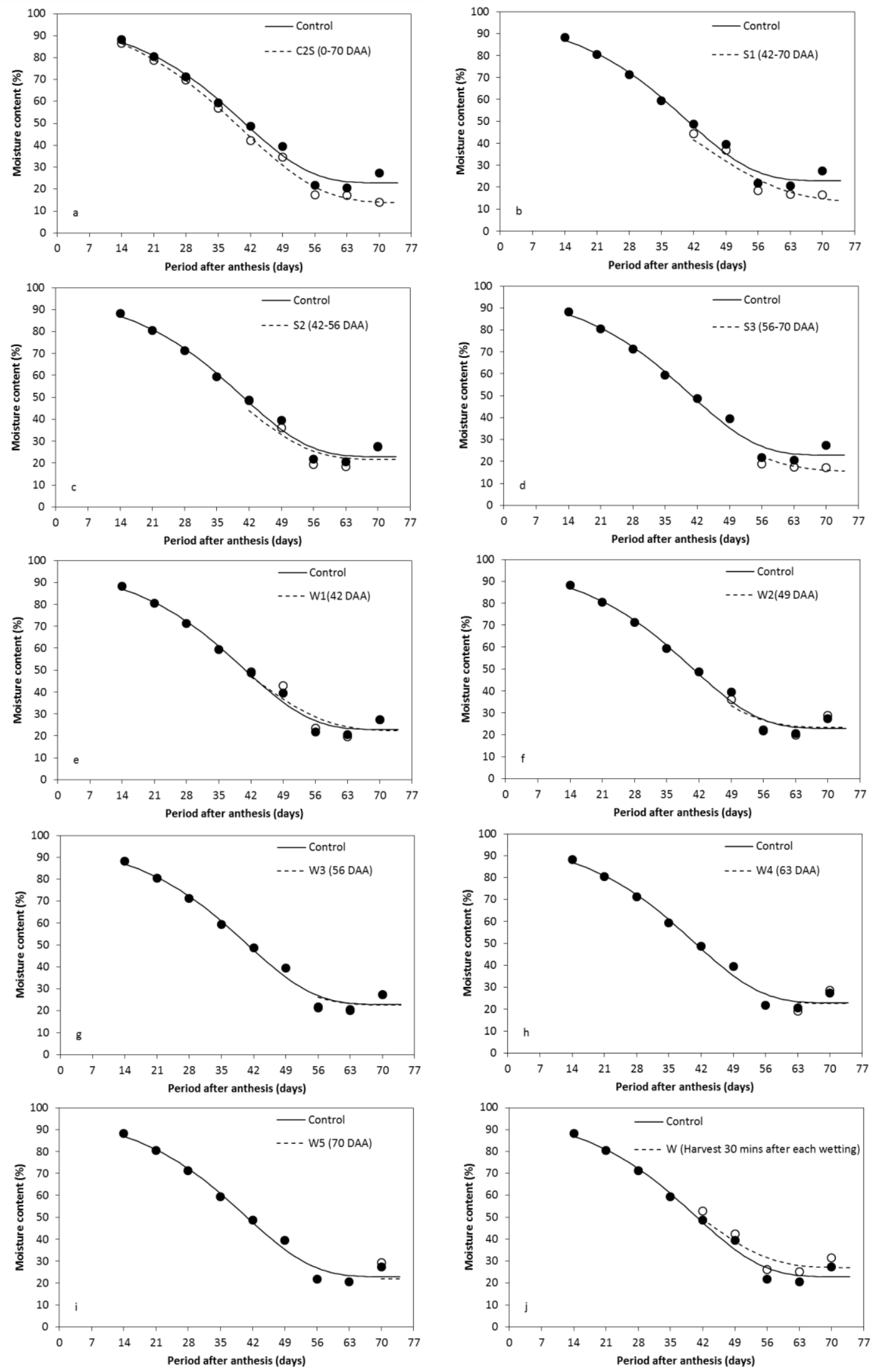

Fig. 3. 

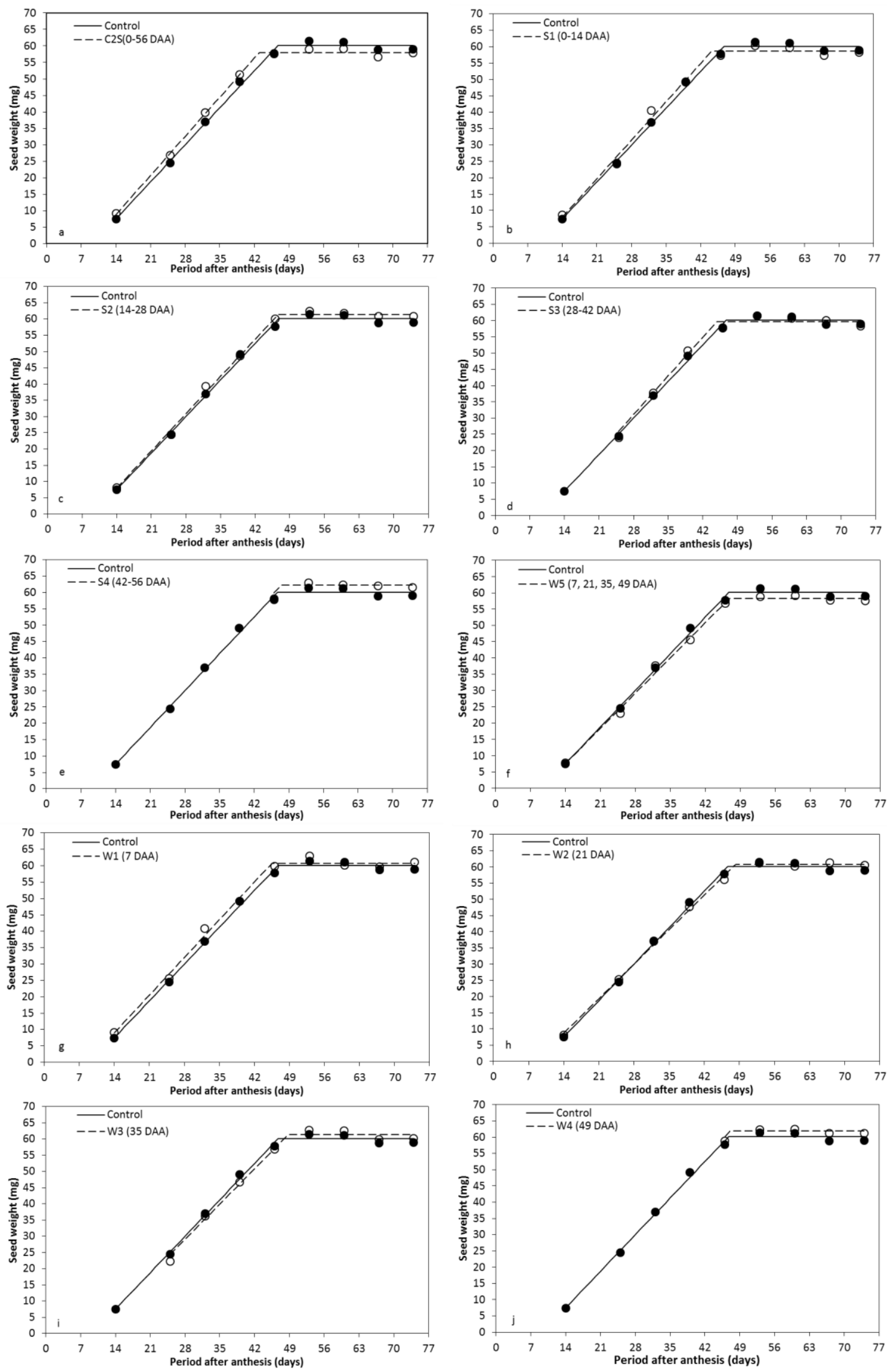

Fig. 4. 

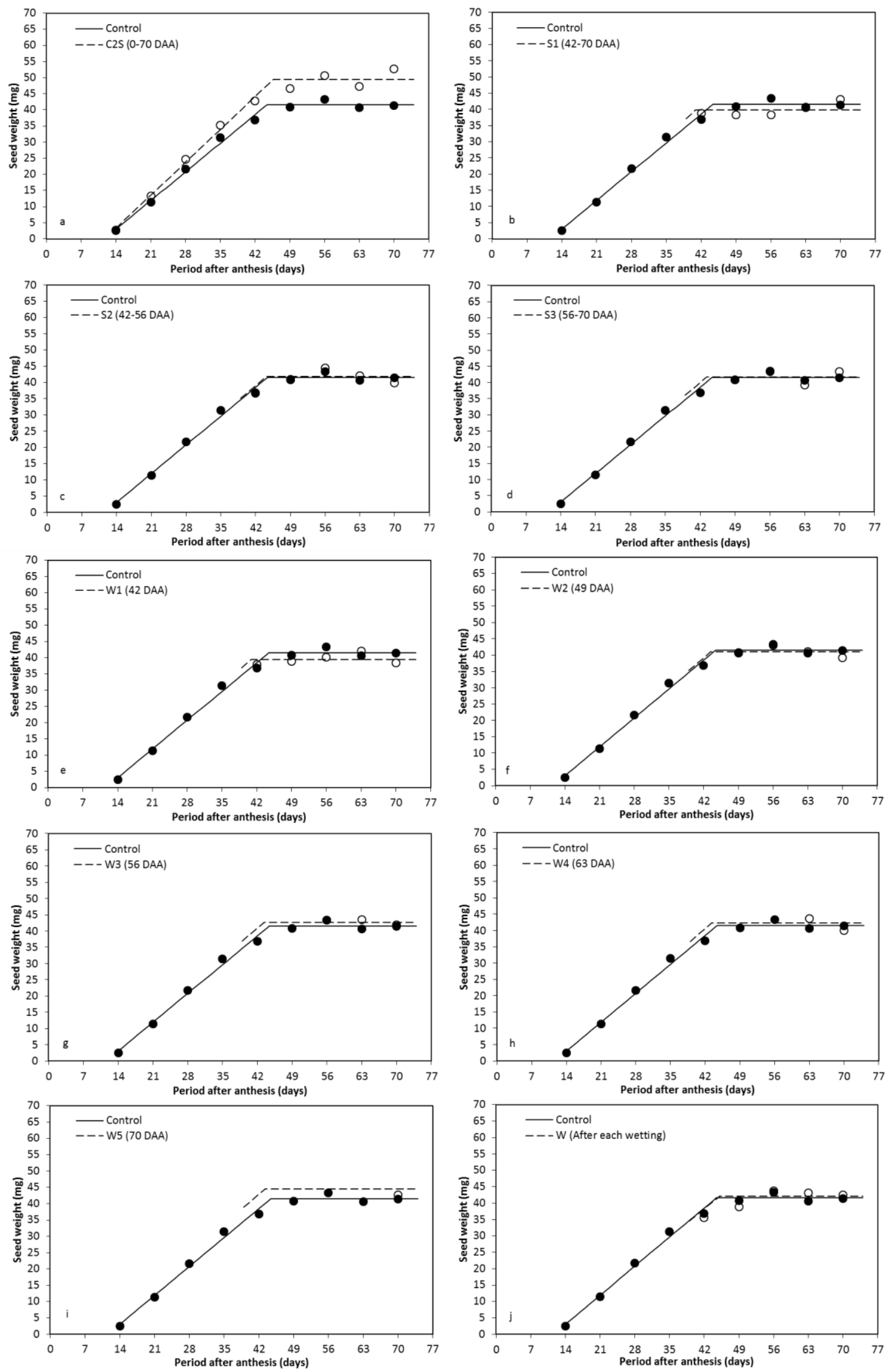

Fig. 5. 

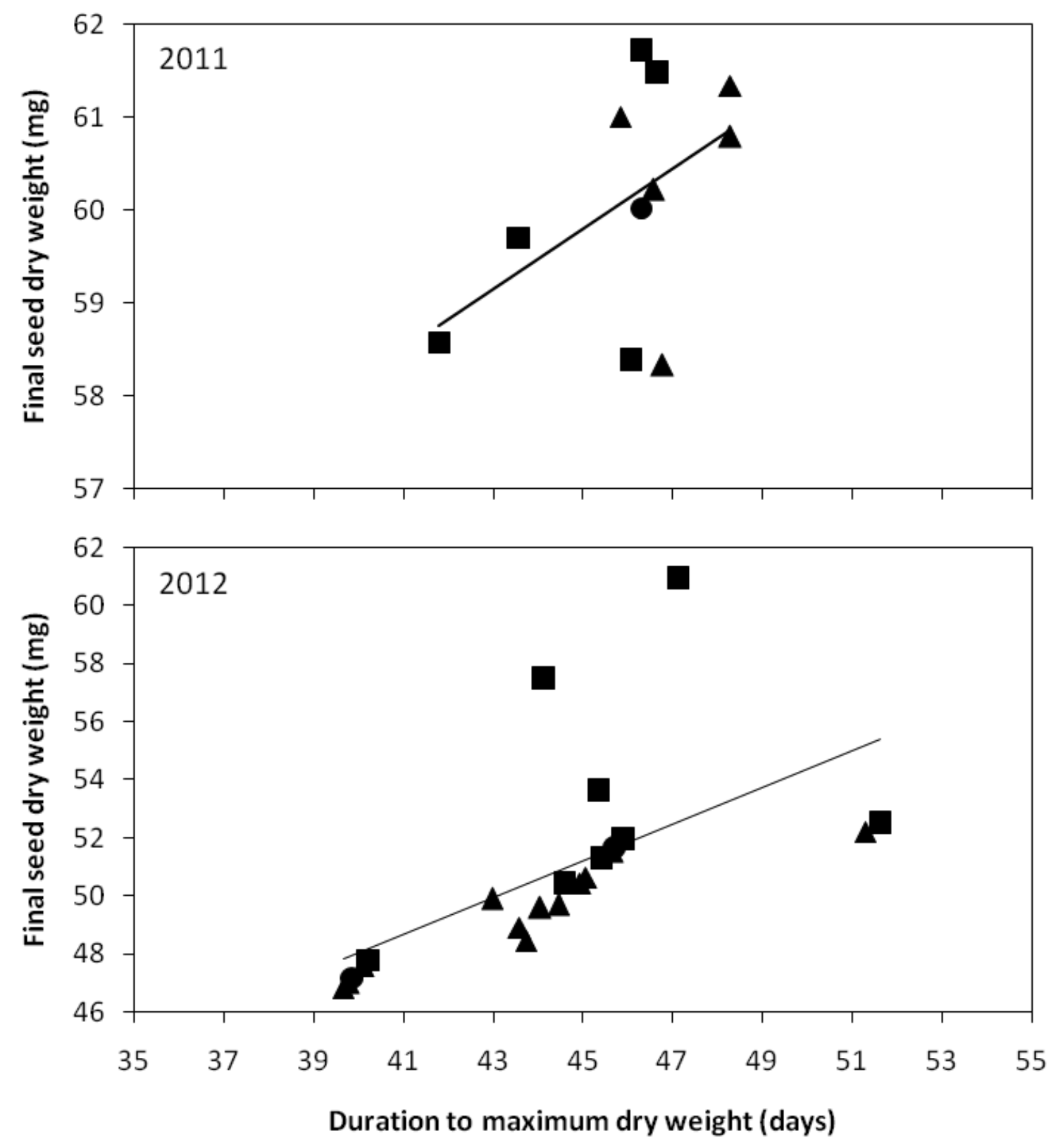

Fig. 6. 

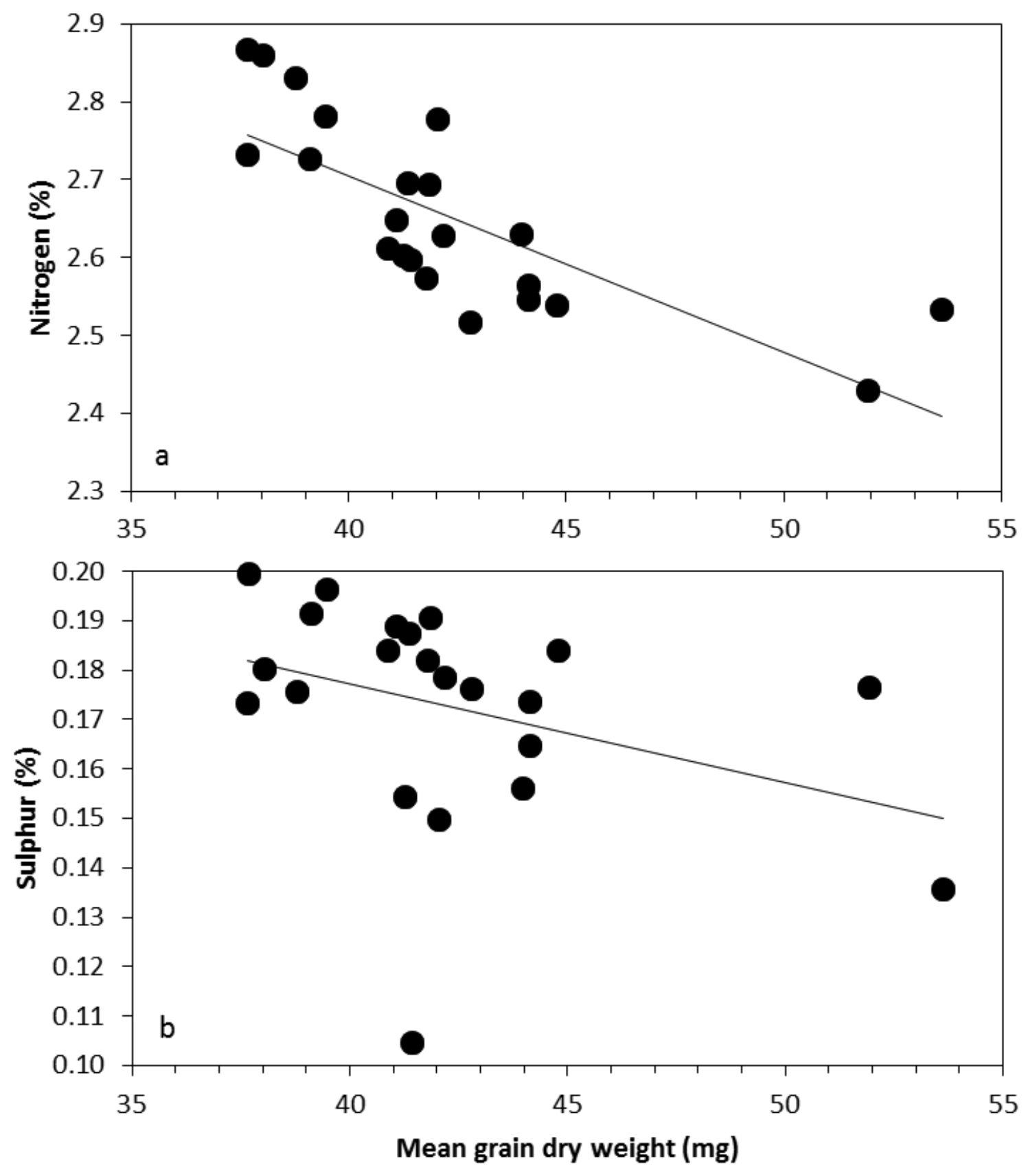

Fig. 7. 